\title{
Etiologi Efusi Pleura pada Pasien Rawat Inap di Rumah Sakit Umum Pusat Sanglah, Denpasar, Bali
} Tahun 2013

\author{
Priscilla Dwianggita \\ Program Studi Pendidikan Dokter, Fakultas Kedokteran Universitas Udayana
}

Diterima: 10 Juni 2016. Disetujui: 20 Juni 2016. Diterbitkan: Agustus 2016

\begin{abstract}
ABSTRAK
Penelitian ini bertujuan untuk mengetahui apa saja penyebab efusi pleura pada pasien rawat inap di Rumah Sakit Umum Pusat Sanglah, Denpasar, Bali tahun 2013. Penelitian ini menggunakan rancangan penelitian deskriptif retrospektif dengan teknik pengambilan sampel systemic random sampling. Penelitian dilakukan dari bulan Agustus-September 2014. Sampel penelitian ialah 107 pasien efusi pleura yang dirawat inap selama tahun 2013. Dikumpulkan data sekunder berupa rekam medis pasien kemudian diolah dan disajikan dalam tabel distribusi frekuensi dan diagram pie. Dari 107 pasien yang diteliti, didapatkan penyebab efusi pleura, yaitu malignansi (34.6\%), pneumonia (15\%), TB paru (10.3\%), demam berdarah (dengue haemorrhagic fever/DHF) (4.7\%), komplikasi post-thoracotomy (2.8\%), systemic lupus erythematous/SLE (0.9\%), gagal jantung kongestif (congestive heart failure/CHF) (15.9\%), gagal ginjal kronis (chronic kidney disease/CKD) (9.3\%), sirosis hepar (3.7\%), dan hipoalbuminemia (2.8\%). Jenis cairan eksudatif (68.2\%) lebih banyak ditemukan daripada transudatif. Efusi pleura eksudatif banyak disebabkan oleh malignansi (50.7\%), sedangkan pada efusi pleura transudatif ialah gagal jantung congestif (50\%). Dapat disimpulkan bahwa terdapat 10 penyebab efusi pleura yang ditemukan pada pasien efusi pleura selama tahun 2013 dengan penyebab terseringnya adalah malignansi. Hasil penelitian ini diharapkan dapat dipergunakan sebagai data awal untuk penelitian selanjutnya.
\end{abstract}

Kata kunci : efusi pleura, etiologi, eksudatif, transudatif

\section{ETIOLOGY OF PLEURAL EFFUSION AMONG HOSPITALIZED PATIENTS IN SANGLAH PUBLIC HOSPITAL, DENPASAR, BALI 2013}

\section{ABSTRACT}

This study was conducted to determine the etiologies of pleural effusion among hospitalized patients in Sanglah Public Hospital, Denpasar, Bali in 2013.

The study was carried out in descriptive retrospective survey. The samples were chosen randomly with systemic random sampling technique and 107 patients with pleural effusion who had been hospitalized in 2013 were chosen. Medical records as the secondary data were collected, organized, then presented in frequency distribution tables and pie charts.

From 107 patients investigated, malignancy, pneumonia, lung TB, dengue haemorrhagic fever/DHF, post-thoracotomy complication, systemic lupus erythematous/SLE, congestive heart failure/CHF, chronic kidney disease/CKD), liver cirrhosis, and hypoalbuminemia were detected as the etiologies of pleural effusion in $34.6 \%, 15 \%, 10.3 \%, 4.7 \%, 2.8 \%, 0.9 \%, 15.9 \%, 9.3 \%, 3.7 \%$, and $2.8 \%$ respectively. Most effusions were exudates (68.2\%). The most commom cause in exudative pleural effusion was malignancy (50.7\%), whereas congestive heart failure (50\%) was the most common cause in transudative pleural effusion. 
Thus, it is concluded that there were 10 etiologies detected in pleural effusion patients throughout 2013 and malignancy was the most common cause. The results of this research hopefully can be applied as a basis for further research.

Keywords : pleural effusion, etiology, exudative, transudative

\section{PENDAHULUAN}

Efusi pleura merupakan kondisi di mana terdapat akumulasi cairan berlebih pada cavitas pleuralis yang disebabkan oleh meningkatnya produksi atau berkurangnya absorpsi cairan pleura. ${ }^{1}$ Cairan biasanya bersumber dari pembuluh darah atau pembuluh limfe, kadang juga disebabkan karena adanya abses atau lesi yang didrainase ke cavitas pleuralis. ${ }^{2}$ Efusi pleura merupakan manifestasi dari banyak penyakit, mulai dari penyakit paru sampai inflamasi sistemik atau malignansi. ${ }^{3}$

Ada dua tipe penyebab utama dari efusi pleura, yaitu efusi pleura transudatif dan eksudatif. Efusi pleura transudatif disebabkan oleh beberapa kombinasi dari peningkatan tekanan hidrostatik atau berkurangnya tekanan onkotik kapiler; misalnya gagal jantung, sirosis, dan sindrom nefrotik. ${ }^{4}$ Efusi pleura eksudatif disebabkan oleh proses lokal yang mengakibatkan perubahan pada pembentukan dan penyerapan cairan pleura; peningkatan permeabilitas kapiler menyebabkan eksudasi cairan, protein, sel, dan komponen serum lainnya Penyebab yang paling sering terjadi, yaitu pnemonia, malignansi, dan pulmonary embolism, infeksi virus, dan tuberculosis. ${ }^{5}$

Oleh karena efusi pleura merupakan manifestasi dari penyakit lain yang mendasari, maka angka insidennya sulit untuk untuk ditentukan. Masih sedikit penelitian dan survey yang telah dilakukan. Namun, beberapa studi menuliskan bahwa estimasi prevalensi efusi pleura adalah 320 dari 100.000 kasus di negara industri di mana persebaran etiologi tergantung dari prevalensi penyakit yang mendasarinya. Frekuensi penyebab efusi pleura juga beragam di bagian tertentu di dunia. Di negara-negara yang sedang berkembang, efusi pleura akibat tuberculosis dan parapneumonic sering ditemukan. ${ }^{6}$ Sedangkan, di negara-negara maju efusi pleura banyak diakibatkan oleh gagal jantung, malignansi, dan pneumonia. ${ }^{7}$ Di Amerika Serikat sendiri, insiden efusi pleura diestimasi mencapai 1,5 juta per tahun. ${ }^{3}$
Di Indonesia, belum ada data nasional yang menggambarkan prevalensi efusi pleura. Namun, beberapa studi telah dilakukan oleh beberapa rumah sakit. Hasil catatan medis di RS Dokter Kariadi Semarang jumlah prevalensi penderita efusi pleura untuk wanita $66,7 . \%$ dan laki-laki 33,3\%. Studi lain di RSUP H. Adam Malik Medan pada tahun 2011 dengan 136 kasus menunjukan prevalensi wanita $34,6 \%$ dan laki-laki $65,4 \% .^{8}$

Untuk mengobati pasien dengan efusi pleura tentunya pengetahuan mengenai etiologinya sangat diperlukan. Etiologi dari efusi pleura sangat beragam dan setiap daerah memiliki perbedaan penyebab efusi pleura yang paling sering ditemui. Rumah Sakit Umum Pusat Sanglah Denpasar, Bali sebagai tempat penelitian merupakan rumah sakit dengan pelayanan komprehensif terbesar di Provinsi Bali dan tentunya tidak sedikit kasus efusi pleura yang terjadi. Di Rumah Sakit Umum Pusat Sanglah Denpasar data mengenai prevalensi efusi pleura selama tiga tahun terakhir masih tidak spesifik, sehingga data tersebut belum mampu digunakan sebagai dasar analisis. Berdasarkan latar belakang tersebut, peneliti memilih untuk melaksanakan penelitian deskriptif retrospektif yang berjudul "Penyebab Efusi Pleura pada Pasien Rawat Inap di Rumah Sakit Umum Pusat Sanglah Denpasar, Bali Tahun 2013".

\section{METODE PENELITIAN}

\section{Rancangan Penelitian}

Penelitian ini menggunakan rancangan atau design penelitian Deskriptif Retrospektif. Penelitian ini merupakan penelitian deskriptif karena dalam pelaksanaannya meliputi pengumpulan data dan mendeskripsikan gambaran data secara objektif. Dan menggunakan pendekatan restrospektif karena penelitian mengambil data dari waktu yang telah berlalu. Penelitian ini bersifat noneksperimen karena tidak melakukan kontrol dan manipulasi terhadap variabel penelitian. Dengan metode ini, hasil penelitian 


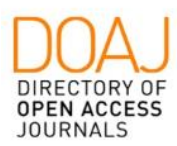

dapat memungkinkan digunakan sebagai data awal untuk analisis dan pengembangan teori yang memiliki validitas universal.

\section{Tempat dan Waktu Penelitian}

Penelitian dilakukan di Ruang Rawat Inap Rumah Sakit Umum Pusat Sanglah, Denpasar, Bali dengan waktu pengumpulan data dimulai pada awal bulan Agustus 2014, yang kemudian akan dikaji selama satu bulan (Agustus-September 2014).

\section{Populasi \& Sampel Penelitian}

1. Populasi

Populasi dalam penelitian ini adalah pasien dengan efusi pleura yang menjalani rawat inap di Rumah Sakit Umum Pusat Sanglah, Denpasar, Bali..

2. Sampel

Sampel merupakan pasien dengan efusi pleura yang menjalani rawat inap di Rumah Sakit Umum Pusat Sanglah, Denpasar, Bali pada tahun 2013.

\section{Besar Sampel, Cara Perhitungan dan Cara Pengambilan Sampel}

1. Besar Sampel

Perkiraan besar sampel untuk penelitian deskriptif retrospektif dengan teknik systematic random sampling, yaitu menggunakan rumus:

$$
\begin{gathered}
n=\frac{z_{\alpha}{ }^{2}(p q)}{d^{2}} \\
n=\frac{1,96^{2}(0,4 \times 0,6)}{0,15^{2}} \\
n=41
\end{gathered}
$$

Keterangan:

$n$ : besar sampel

$z_{\alpha}$ : sama dengan 1,96 pada confidence interval $95 \%$

$p$ : proporsi minimal populasi target

$q: 1-p$

$d$ : ketepatan absolut yang dipakai (ditetapkan oleh peneliti $=10 \%$ )

$$
n 2=n 1+10 \% n 1
$$

besar sampel ditambah substitusi $10 \%$ (substitusi adalah persen pasien yang mungkin dropout

$$
\begin{gathered}
n 1=\frac{(1,96)^{2} \quad 0,5 \quad 0,5}{(0,1)^{2}}=96,04 \quad 97 \\
n 2=97+\left(\begin{array}{ll}
10 \% & 97)=106,7 \quad 107
\end{array}\right.
\end{gathered}
$$

Maka, dari hasil perhitungan diatas besar sampel penelitian yang diperlukan untuk dapat mewakili populasi adalah 107 orang.

\section{Cara Pengambilan Sampel}

Pengambilan sampel dilakukan dengan teknik systematic random sampling, yakni ditentukan dari seluruh subjek yang dapat dipilih, setiap subjek nomor ke-sekian dipilih sebagai sampel. Sebelumnya ditentukan terlebih dahulu interval, yaitu $1 / n$ dari populasi. Kemudian, setiap subjek nomor ke-n dipilih sebagai sampel penelitian.

\section{Variabel Penelitian}

1. Variabel bebas penelitian : penyakit yang mendasari efusi pleura.

2. Variabel tergantung penelitian : efusi pleura transudatif dan efusi pleura eksudatif.

\section{Definisi Operasional Variabel}

1) Pasien efusi pleura adalah pasien dengan akumulasi cairan yang berlebihan pada cavitas pleuralis yang telah didiagnosis atau suspect setelah dilakukannya anamnesis, pemeriksaan fisik, dan pemeriksaan penunjang. ${ }^{5}$

2) Efusi pleura transudatif adalah efusi pleura dengan kadar protein $<30 \mathrm{~g} / \mathrm{l}$ atau tidak memenuhi kriteria Light. $^{9}$

3) Efusi pleura eksudatif adalah efusi pleura dengan kadar protein $>30 \mathrm{~g} / \mathrm{l}$ atau memenuhi kriteria Light.

4) Gagal jantung kiri adalah kondisi gagal jantung di mana ventrikel kiri jantung tidak mampu berkontraksi maksimal untuk mempertahankan output jantung dan perfusi perifer yang cukup. ${ }^{10}$ Pasien mengalami efusi pleura akibat gagal jantung apabila pasien secara klinis memang mengalami gagal jantung dengan gejala sesak nafas, dyspnea, berkeringat, orthopnea, pucat, vasokontriksi perifer, pembesaran jantung, distensi vena pada leher, dan terdengarnya suara 
jantung ketiga (gallop) yang jelas. Diagnosis bisa dilakukan dengan tes ekokardiografi. ${ }^{7}$

5) Sirosis hati merupakan terbentuknya fibrosis pada hati di mana terjadinya distorsi arsitektural karena pembentukan nodul regeneratif yang mengakibatkan menurunnya fungsi hati. Diagnosisnya dipastikan melalui pemeriksaan histopatologi. ${ }^{5}$

6) Hipoalbuminaemia adalah kondisi di mana serum albumin di dalam darah rendah yang dapat menyebabkan terjadinya edema melalui penurunan tekanan onkotik kapiler. Serum albumin dikatakan rendah apabila $<3,5 \mathrm{~g} / \mathrm{dl}$ di dalam darah. ${ }^{11}$

7) Dialisis peritoneal merupakan proses dialisis yang bertujuan untuk membuang produk sisa dan kelebihan cairan di dalam cavitas peritoneal di mana darah tetap dibersihkan di dalam tubuh bukan di dalam mesin. Abdomen akan diisi dengan cairan dialisis dan peritoneum berfungsi seperti membran artifisial dari alat dialisis. Produk sisa dan kelebihan cairan di dalam darah akan melewati peritoneum ke cairan dialisis. Cairan ini nantinya akan dikeluarkan dari tubuh dan dibuang. Proses ini berlangsung 4-6 kali dalam 24 jam. $^{12}$

8) Sindrom nefrotik merupakan penyakit ginjal dengan karakteristik adanya albuminuria (>3,5 g/hari), hipoalbuminemia (<30 g/L), dan disertai adanya edema, hiperlipidemia, dan lipiduria. ${ }^{5}$

9) Emboli paru/pulmonary embolism (PE) merupakan penyumbatan pada arteri paru ataupun cabangcabangnya akibat Deep-vein thrombosis (DVT) pada ekstremitas bawah yang bermigrasi ke sirkulasi arteri paru. PE umumnya menunjukkan gejala dyspnea dan bisa juga terjadi syncope. Pada pemeriksaan fisik akan ditemukan takipnea dan takikardi. Foto x-ray dada normal sering dilakukan dan CT dada dengan kontras IV menjadi tes diagnostik utama untuk PE. ${ }^{5}$

10) Malignansi merupakan sel kanker yang mampu bermetastasis ke bagian tubuh lainnya dan menginvasi organ tersebut. Kanker yang banyak menyebabkan efusi pleura, yaitu kanker paru, kanker payudara, dan limfoma. ${ }^{5}$ Diagnosisnya dapat dilakukan pemeriksaan sitologi dan/atau histologi.

11) Efusi parapnemonia merupakan tipe dari efusi pleura yang terjadi karena adanya infeksi bakteri berkelanjutan pada paru, termasuk pnemonia dan abses paru atau bronkiektasis. ${ }^{5}$
12) Tuberculosis merupakan infeksi bakteri pada paru; efusi pleura tuberculosis merupakan bentuk yang sering ditemukan pada tuberculosis ekstrapulmonari. Diagnosis dapat ditegakkan apabila ditemukan $\mathrm{M}$. Tuberculosis pada sputum, cairan pleura, atau spesimen biopsi pleura. Adanya TB markers yang tinggi pada cairan pleura, seperti ADA, interferon ? atau reaksi rantai polimerasi positif apda DNA TB juga mampu menegakkan diagnosis. ${ }^{5}$

13) Penyakit autoimun yang dimaksud yaitu pasien dengan systemic lupus erythematosus (SLE). SLE adalah penyakit autoimun kronis yang dapat mengenai berbagai organ tubuh, sehingga manifestasi sangat beragam. Diagnosis ditegakkan dari berbagai macam temuan klinis dan hasil laboratorium. ${ }^{5}$

14) Rheumatoid arthritis merupakan penyakit multisistem kronis yang tidak diketahui etiologinya. Penyakit ini memiliki karakteristik inflamasi sinovitis persisten yang simetris. RA mengenai bagian perifer sendi-sendi tangan dan kaki yang menimbulkan rasa nyeri dan bengkak yang dapat mengakibatkan terjadinya erosi tulang dan deformitas sendi. ${ }^{5}$

\section{Bahan dan Instrumen Penelitian}

1. Rekam medis data pasien dengan efusi pleura yang menjalani rawat inap di RSUP Sanglah Denpasar tahun 2013.

2. Alat tulis

3. Buku panduan penulisan usulan penelitian

4. Laptop

\section{Kelemahan Penelitian}

Data yang dikaji pada saat penelitian hanya dilaksanakan dalam satu waktu pengambilan data dan tanpa analisis, sehingga pemanfaatan temuan penelitian ini berlaku terbatas pada prevalensi penyebab efusi pleura pada tahun 2013 tersebut, yang belum tentu relevan dengan waktu yang akan datang.

\section{Analisis Data}

Hasil yang diperoleh akan diolah dan disajikan dalam bentuk tabel distribusi frekuensi kemudian dipaparkan secara deskriptif untuk menunjukkan jumlah dan apa saja penyebab efusi pleura pada pasien rawat inap di Rumah Sakit Umum Pusat Sanglah, Denpasar, Bali selama tahun 2013. 


\section{HASIL DAN PEMBAHASAN}

Total pasien efusi pleura yang dirawat inap di RSUP Sanglah Denpasar selama tahun 2013 adalah 483 pasien. Pada penelitian ini diambil subjek sebanyak 107 pasien. Data diambil dari rekam medis pasien yang selanjutnya diolah berdasarkan umur, jenis kelamin, jenis cairan efusi pleura, dan lokasi cairan efusi pleura yang akan disajikan dalam bentuk tabel dan diagram pie.

\section{Distribusi Proporsi Pasien Efusi Pleura Berdasarkan Jenis Kelamin}

Tabel 5.1 Distribusi Proporsi Pasien Efusi Pleura Berdasarkan Jenis Kelamin

\begin{tabular}{lll}
\hline Jenis Kelamin & Jumlah $(\mathrm{n})$ & Persentase (\%) \\
\hline Laki-laki & 61 & 57 \\
Perempuan & 46 & 43 \\
\hline & 107 & 100 \\
\hline
\end{tabular}

Dari Tabel 5.1 didapatkan sebagian besar subjek penelitian adalah laki-laki sebanyak 61 (57\%) pasien dan sisanya adalah perempuan sebanyak 46 (43\%) pasien. Hal ini sesuai dengan hasil penelitian Tobing (2013) dan Khan dkk (2011) yang menyatakan proporsi tertinggi pasien efusi pleura berdasarkan jenis kelamin adalah laki-laki, yaitu 65,4\% dan 76\%. Jadi, laki-laki memiliki proporsi yang lebih tinggi pada pasien efusi pleura. ${ }^{6-8}$

\section{Distribusi Proporsi Pasien Efusi Pleura Berdasarkan Usia}

Tabel 5.2 Distribusi Proporsi Pasien Efusi Pleura Berdasarkan Usia

\begin{tabular}{lll}
\hline Kelompok Usia & Jumlah $(\mathrm{n})$ & Persentase $(\%)$ \\
\hline$<40$ tahun & 29 & 27,1 \\
$40-59$ tahun & 53 & 49,5 \\
$60-79$ tahun & 23 & 21,5 \\
$>80$ tahun & 2 & 1,9 \\
\hline & 107 & 100 \\
\hline
\end{tabular}

Dari Tabel 5.2 didapatkan kelompok usia 40-59 tahun $(49,5 \%)$ ialah kelompok usia dengan proporsi tertinggi, sedangkan usia $>80$ tahun merupakan proporsi terendah (1,9\%). Usia termuda didapatkan 1 bulan 19 hari dan usia tertua 97 tahun dengan rerata usia pasien efusi pleura adalah 47,69 tahun. Hal ini sesuai dengan hasil penelitian Tobing (2013) di mana kelompok umur mayoritas adalah 45-59 tahun dengan persentase sebesar $32,4 \%$. Namun, hasil penelitian ini berbeda dengan penelitian Desalew (2012) di Ethiopia yang menyatakan kelompok umur $<40$ tahun ialah kelompok umur yang paling banyak menderita efusi pleura dengan rerata umur 37 tahun. Hal ini disebabkan oleh karena perbedaan lokasi penelitian sehingga distribusi penyakit yang mendasari efusi pleura yang berhubungan dengan umur pasien juga berbeda-berbeda. Jadi, rerata usia dan kelompok usia mayoritas pasien efusi pleura berbeda-beda di setiap wilayah.

\section{Distribusi Proporsi Pasien Efusi Pleura Berdasarkan Lokasi Cairan}

Tabel 5.3 Distribusi Proporsi Pasien Efusi Pleura

Berdasarkan Lokasi Cairan

\begin{tabular}{lll}
\hline Lokasi Cairan & Jumlah (n) & Persentase (\%) \\
\hline Kanan & 38 & 35,5 \\
Kiri & 27 & 25,2 \\
Bilateral & 42 & 39,3 \\
\hline & 107 & 100 \\
\hline
\end{tabular}

Dari Tabel 5.3 didapatkan lokasi cairan efusi pleura dengan proporsi tertinggi ialah bilateral (39,3\%), lalu disusul oleh hemitoraks kanan sebesar 35,5\% dan kiri 25,2\%. Apabila digolongkan menjadi unilateral dan bilateral, maka efusi pleura lebih banyak terjadi pada satu sisi hematoraks (unilateral), yaitu sebanyak 65 $(60,7 \%)$ pasien. Hasil penelitian tidak sesuai dengan hasil penelitian Khan (2011), Tobing (2011), dan Desalew (2012) yang menyatakan cairan efusi pleura lebih banyak ditemukan pada hemitoraks kanan dibandingkan hemitoraks kiri, maupun bilateral; dengan masing-masing persentasenya sebesar $54,5 \%$, $50 \%$, dan $45,5 \%$. $^{6-8}$

Pada penelitian ini juga ditemukan lebih banyak cairan pleura pada hemitoraks kanan pada efusi pleura unilateral, tetapi tidak lebih banyak daripada efusi pleura bilateral. Hal ini disebabkan distribusi penyebab efusi pleura yang berbeda-beda di setiap daerah sehingga lokasi cairan pun berbeda. 
Gambar 5.1 Diagram Prevalensi Penyebab Efusi Pleura

\section{Distribusi Proporsi Pasien Efusi Pleura Berdasarkan Jenis Cairan}

Tabel 5.4 Distribusi Proporsi Pasien Efusi Pleura Berdasarkan Jenis Cairan

\begin{tabular}{lll}
\hline Jenis Cairan & Jumlah (n) & Persentase (\%) \\
\hline Eksudatif & 73 & 68,2 \\
Transudatif & 34 & 31,8 \\
\hline & 107 & 100 \\
\hline
\end{tabular}

Dari Tabel 5.4 bisa dilihat bahwa efusi pleura eksudatif lebih banyak ditemukan pada penelitian ini, yaitu sebanyak $73(68,2 \%)$ pasien dibandingkan dengan efusi pleura transudatif (31,8\%). Hal ini sesuai dengan penelitian Khan (2011) yang mendapatkan hasil 79\% dari 200 pasien efusi pleura memiliki jenis cairan eksudatif. Jadi, efusi pleura banyak yang memiliki jenis cairan eksudatif karena banyak efusi pleura yang disebabkan oleh peningkatan permeabilitas kapiler sehingga terjadi eksudasi cairan, protein, sel, dan komponen serum lainnya ke cavitas peluralis.

\section{Prevalensi Penyebab Efusi Pleura}

Tabel 5.5 Prevalensi Penyebab Efusi Pleura

\begin{tabular}{lll}
\hline Penyebab Efusi & $\begin{array}{l}\text { Jumlah } \\
\text { (n) }\end{array}$ & $\begin{array}{l}\text { Persentase } \\
\text { (\%) }\end{array}$ \\
\hline Malignansi & 37 & 34,6 \\
CHF & 17 & 15,9 \\
Pneumonia & 16 & 15,0 \\
TB Paru & 11 & 10,3 \\
CKD & 10 & 9,3 \\
DHF & 5 & 4,7 \\
Sirosis hepar & 4 & 3,7 \\
Post-Thoracotomy & 3 & 2,8 \\
Hipoalbuminemia & 3 & 2,8 \\
SLE & 1 & 0,9 \\
\hline Total & 107 & 100 \\
\hline
\end{tabular}

Catatan : TB=Tuberculosis; DHF=Dengue Haemorrhagic Fever; SLE=systemic lupus erythematous; $\mathrm{CHF}=$ congestive heart failure; $\mathrm{CKD}=$ chronic kidney disease.

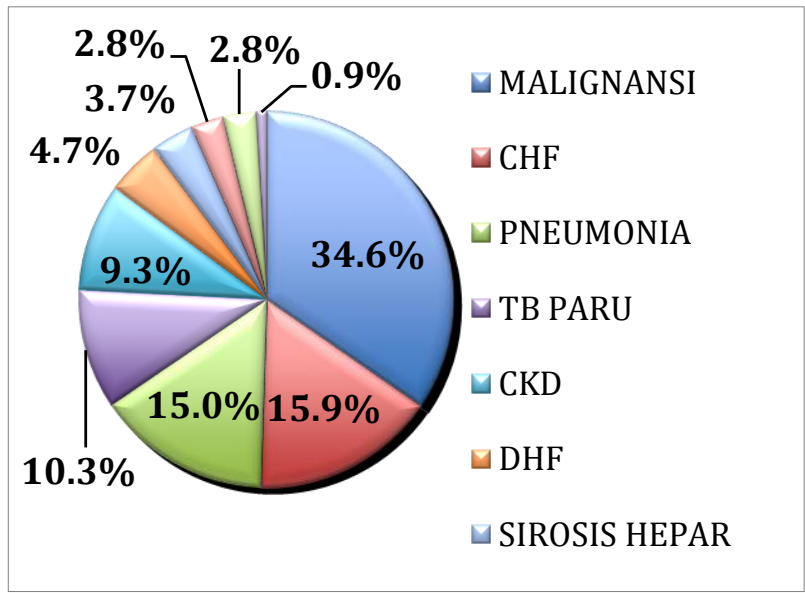

Dari Tabel 5.5 dan Gambar 5.1 didapatkan sepuluh penyebab efusi pleura pada 107 pasien, yaitu malignansi (34,6\%), pneumonia (15\%), TB paru $(10,3 \%)$, demam berdarah (dengue haemorrhagic fever/DHF) $(4,7 \%)$, komplikasi post-thoracotomy $(2,8 \%)$, systemic lupus erythematous/SLE (0,9\%), gagal jantung kongestif (congestive heart failure/CHF) $(15,9 \%)$, gagal ginjal kronis (chronic kidney disease/CKD) (9,3\%), sirosis hepar $(3,7 \%)$, dan hipoalbuminemia (2,8\%). Penyebab efusi pleura yang paling banyak adalah malignansi sebanyak 37 pasien dan yang paling sedikit adalah SLE sebanyak 1 orang.

Hal ini tidak sesuai dengan hasil penelitian Khan (2011) dan Tobing (2011) yang menyatakan penyebab efusi pleura yang paling banyak ialah TB paru, yaitu sebesar 32,5\% dan 44,1\%. Hasil penelitian Khan (2011) ditemukan penyebab efusi pleura kedua terbanyak setelah TB paru ialah pneumonia (19\%), diikuti oleh malignansi $(15,5 \%)$ dan gagal jantung (13\%). Perbedaan ini bisa dikarenakan perbedaan lokasi sehingga distribusi penyakit penyebab efusi pleura pun berbedabeda tergantung wilayah.

\section{Distribusi Proporsi Penyebab Efusi Pleura}

1. Berdasarkan Jenis Kelamin

Tabel 5.6(a) Distribusi Proporsi Penyebab Efusi Pleura Berdasarkan Jenis Kelamin (a)

\begin{tabular}{|c|c|c|c|c|c|}
\hline Jenis & Malignansi & $\mathrm{CHF}$ & Pneumonia & TB Paru & CKD \\
\hline Kelamin & $\%$ & $\%$ & $\%$ & $\%$ & $\mathrm{n}$ \\
\hline
\end{tabular}




\begin{tabular}{lllllllllll}
\hline Laki-laki & 18 & 48,6 & 10 & 58,8 & 10 & 62,5 & 7 & 63,6 & 6 & 60 \\
Perempuan & 19 & 51,4 & 7 & 41,2 & 6 & 37,5 & 4 & 36,4 & 4 & 40 \\
\hline & 37 & 100 & 17 & 100 & 16 & 100 & 11 & 100 & 10 & 100 \\
\hline
\end{tabular}

Tabel 5.6(b) Distribusi Proporsi Penyebab Efusi Pleura Berdasarkan Jenis Kelamin (b)

\begin{tabular}{|c|c|c|c|c|c|c|c|c|c|c|}
\hline \multirow{2}{*}{ Jenis Kelamin } & \multicolumn{2}{|c|}{ DHF } & \multicolumn{2}{|c|}{$\begin{array}{l}\text { Sirosis } \\
\text { hepar }\end{array}$} & \multicolumn{2}{|c|}{$\begin{array}{l}\text { Post- } \\
\text { thoracotomy }\end{array}$} & \multicolumn{2}{|c|}{$\begin{array}{l}\text { Hipo } \\
\text { albuminemia }\end{array}$} & \multicolumn{2}{|c|}{ SLE } \\
\hline & $\mathrm{n}$ & $\%$ & $\mathrm{n}$ & $\%$ & $\mathrm{n}$ & $\%$ & $\mathrm{n}$ & $\%$ & $n$ & $\%$ \\
\hline Laki-laki & 3 & 60 & 3 & 75 & 3 & 100 & 1 & 33,3 & 0 & 0 \\
\hline \multirow[t]{2}{*}{ Perempuan } & 2 & 40 & 1 & 25 & 0 & 0 & 2 & 66,7 & 1 & 100 \\
\hline & 5 & 100 & 4 & 100 & 3 & 100 & 3 & 100 & 1 & 100 \\
\hline
\end{tabular}

Dari Tabel 5.6 (a) dan (b) didapatkan laki-laki lebih banyak mengalami efusi pleura yang disebabkan oleh CHF $(58,8 \%)$, pneumonia $(62,5 \%)$, TB paru $(63,6 \%)$, CKD (60\%), DHF (60\%), dan komplikasi postthoracotomy (100\%). Sedangkan efusi pleura yang disebabkan oleh malignansi, hipoalbuminemia, dan SLE lebih banyak diderita perempuan, yaitu masingmasing sebesar $51,4 \%, 66,7 \%$, dan $100 \%$. Namun, pada malignansi laki-laki maupun perempuan tidak memiliki rentang frekuensi yang terlalu besar.

\section{Berdasarkan Usia}

Tabel 5.7(a) Distribusi Proporsi Penyebab Efusi Pleura Berdasarkan Usia (a)

\begin{tabular}{lllllllllll}
\hline Kelompok & \multicolumn{2}{l}{ Malignansi } & \multicolumn{2}{l}{ CHF } & \multicolumn{3}{c}{ Pneumonia } & \multicolumn{2}{c}{ TB Paru } & \multicolumn{2}{c}{ CKD } \\
Usia & $\mathrm{n}$ & $\%$ & $\mathrm{n}$ & $\%$ & $\mathrm{n}$ & $\%$ & $\mathrm{n}$ & $\%$ & $\mathrm{n}$ & $\%$ \\
\hline$<40$ tahun & 8 & 21,6 & 2 & 11,8 & 8 & 50 & 3 & 27,3 & 0 & 0 \\
40-59 tahun & 17 & 46 & 10 & 58,8 & 6 & 37,5 & 5 & 45,4 & 9 & 90 \\
$60-79$ tahun & 11 & 29,7 & 4 & 23,5 & 2 & 12,5 & 3 & 27,3 & 1 & 10 \\
$>80$ tahun & 1 & 2,7 & 1 & 5,9 & 0 & 0 & 0 & 0 & 0 & 0 \\
\hline & 37 & 100 & 17 & 100 & 16 & 100 & 11 & 100 & 10 & 100 \\
\hline
\end{tabular}

Tabel 5.7(b) Distribusi Proporsi Penyebab Efusi Pleura Berdasarkan Usia (b)

\begin{tabular}{|c|c|c|c|c|c|c|c|c|c|c|}
\hline \multirow{2}{*}{$\begin{array}{l}\text { Kelompok } \\
\text { Usia }\end{array}$} & \multicolumn{2}{|c|}{ DHF } & \multicolumn{2}{|c|}{$\begin{array}{l}\text { Sirosis } \\
\text { hepar }\end{array}$} & \multicolumn{2}{|c|}{$\begin{array}{l}\text { Post- } \\
\text { thoracotomy }\end{array}$} & \multicolumn{2}{|c|}{$\begin{array}{l}\text { Hipo } \\
\text { albuminemia }\end{array}$} & \multicolumn{2}{|c|}{ SLE } \\
\hline & $\mathrm{n}$ & $\%$ & $n$ & $\%$ & $n$ & $\%$ & $\mathrm{n}$ & $\%$ & $\mathrm{n}$ & $\%$ \\
\hline$<40$ tahun & 4 & 80 & 1 & 25 & 0 & 0 & 2 & 66,7 & 1 & 100 \\
\hline 40-59 tahun & 1 & 20 & 3 & 75 & 2 & 66,7 & 0 & 0 & 0 & 0 \\
\hline 60-79 tahun & 0 & 0 & 0 & 0 & 1 & 33,3 & 1 & 33,3 & 0 & 0 \\
\hline \multirow[t]{2}{*}{$>80$ tahun } & 0 & 0 & 0 & 0 & 0 & 0 & 0 & 0 & 0 & 0 \\
\hline & 5 & 100 & 4 & 100 & 3 & 100 & 3 & 100 & 1 & 100 \\
\hline
\end{tabular}

Berdasarkan Tabel 5.7 (a) dan (b) bisa dilihat bahwa hampir semua penyebab efusi pleura diderita oleh pasien dengan usia 40-59 tahun. Kecuali pneumonia, DHF, dan hipoalbuminemia lebih banyak diderita pada pasien usia <40 tahun, yaitu masing-masing sebesar $50 \%, 80 \%$, dan $66,7 \%$. Hanya ditemukan 1 pasien SLE sehingga persentasenya menunjukkan $100 \%$ untuk kelompok usia $<40$ tahun.

Pada penelitian Khan (2011) kelompok usia hanya dibedakan menjadi 2, yaitu 15-64 tahun dan $\geq 65$ tahun. Dari hasil penelitian tersebut didapatkan penyebab efusi pleura TB, pneumonia, malignansi, 


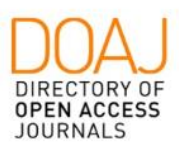

dan gagal jantung banyak terdapatkan pada kelompok usia 15-64 tahun dengan persentase masing-masing $96,9 \%, 89,5 \%, 74,5 \%$, dan $57,7 \%$. Hal ini bisa
E- ISSN: 2503-3638, Print ISSN: 2089-9084

ISM VOL. 7 NO.1, SEPTEMBER-DESEMBER, HAL 57-66 disebabkan perbedaan usia mayoritas pada populasi

di Qatar dan di Indonesia, khususnya Bali.

\section{Berdasarkan Lokasi Cairan}

Tabel 5.8 Distribusi Proporsi Penyebab Efusi Pleura Berdasarkan Lokasi Cairan

\begin{tabular}{llllllll}
\hline \multirow{2}{*}{ Penyebab Efusi Pleura } & \multicolumn{3}{l}{ Hemitoraks Kanan } & \multicolumn{3}{l}{ Hemitoraks Kiri } & \multicolumn{2}{c}{ Bilateral } & Total \\
& $\mathrm{n}$ & $\%$ & $\mathrm{n}$ & $\%$ & $\mathrm{n}$ & $\%$ & \\
\hline Malignansi & 15 & 40,6 & 9 & 24,3 & 13 & 35,1 & 37 \\
CHF & 3 & 17,6 & 1 & 5,9 & 13 & 76,5 & 17 \\
Pneumonia & 6 & 37,5 & 6 & 37,5 & 4 & 25 & 16 \\
TB Paru & 6 & 54,5 & 3 & 27,3 & 2 & 18,2 & 11 \\
CKD & 1 & 10 & 3 & 30 & 6 & 60 & 10 \\
DHF & 2 & 40 & 0 & 0 & 3 & 60 & 5 \\
Sirosis hepar & 3 & 75 & 1 & 25 & 0 & 0 & 4 \\
Post-Thoracotomy & 1 & 33,3 & 2 & 66,7 & 0 & 0 & 3 \\
Hipoalbuminemia & 1 & 33,3 & 1 & 33,3 & 1 & 33,3 & 3 \\
SLE & 0 & 0 & 1 & 100 & 0 & 0 & 1 \\
\hline Total n & 38 & 35,5 & 27 & 25,2 & 42 & 39,3 & 107 \\
\hline
\end{tabular}

Dari Tabel 5.8 didapatkan efusi pleura dengan etiologi malignansi, TB paru, dan sirosis hepar lebih banyak menyerang hemitoraks kanan, yaitu sebesar $40,6 \%$, $54,5 \%$, dan $75 \%$ secara berturut-turut. Namun, pada pasien CHF efusi pleura sebagian besar ditemukan pada kedua sisi hematoraks (bilateral), yaitu sebesar $76,5 \%$. Sedangkan, pada pasien pneumonia, hemitoraks kanan dan kiri memiliki proporsi yang sama terjadinya efusi pleura.

Hasil penelitian pada pasien TB paru dan malignansi di atas konsisten dengan penelitian Khan (2011) yang mendapatkan hasil hemitoraks kanan lebih sering dijumpai efusi pleura akibat TB paru (56,9\%) dan malignansi (54,9\%). Sedangkan, efusi pleura akibat pneumonia didapatkan sebagian besar pada hemitoraks kanan $(55,3 \%)$ dan CHF didapatkan proporsi yang sama antara hemitoraks kanan dan bilateral, yakni $46,2 \%$.

\section{Prevalensi Penyebab Efusi Pleura Eksudatif}

Gambar 5.2 Diagram Prevalensi Penyebab Efusi Pleura Eksudatif.

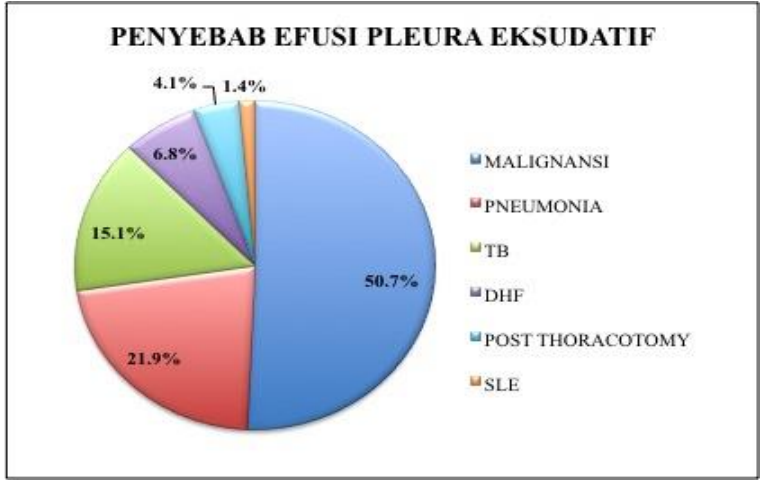

Tabel 5.9 Prevalensi Penyebab Efusi Pleura Eksudatif

\begin{tabular}{lll}
\hline $\begin{array}{l}\text { Penyebab Efusi } \\
\text { Eksudatif }\end{array}$ & Jumlah (n) & $\begin{array}{l}\text { Persentase } \\
(\%)\end{array}$ \\
\hline Malignansi & 37 & 50,7 \\
Pneumonia & 16 & 21,9 \\
TB Paru & 11 & 15,1 \\
DHF & 5 & 6,8 \\
Post Thoracotomy & 3 & 4,1 \\
SLE & 1 & 1,4 \\
\hline & 73 & 100
\end{tabular}


Dari Gambar 5.2 dan Tabel 5.9 bisa dilihat bahwa 73 pasien efusi pleura eksudatif, paling banyak disebabkan oleh malignansi, yaitu sebanyak 37 $(50,7 \%)$ pasien, diikuti oleh pneumonia 16 (21\%) pasien, TB paru $11(15,1 \%)$ pasien, DHF 5 (6,8\%) pasien, komplikasi post-thoracotomy $3(4,1 \%)$ pasien, dan $1(1,4 \%)$ pasien SLE.

Hal ini tidak sesuai dengan hasil penelitian Khan (2011), pada penelitian tersebut didapatkan penyebab efusi pleura eksudatif paling banyak oleh karena TB paru (41,1\%), diikuti oleh pneumonia (24\%) dan malignansi $(19,6 \%)$. Perbedaan ini disebabkan oleh perbedaan etiologi efusi pleura di tiap daerah yang berbeda-beda tergantung prevalensi penyakit yang mendasari di wilayah tersebut.

\section{Prevalensi Penyebab Efusi Pleura Transudatif}

Tabel 5.10 Prevalensi Penyebab Efusi Pleura Transudatif

\begin{tabular}{lll}
\hline $\begin{array}{l}\text { Penyebab Efusi } \\
\text { Pleura Transudatif }\end{array}$ & $\begin{array}{l}\text { Jumlah } \\
(\mathrm{n})\end{array}$ & $\begin{array}{l}\text { Persentase } \\
(\%)\end{array}$ \\
\hline CHF & 17 & 50 \\
CKD & 10 & 29,4 \\
Sirosis hepar & 4 & 11,8 \\
Hipoalbuminemia & 3 & 8,8 \\
\hline & 34 & 100 \\
\hline
\end{tabular}

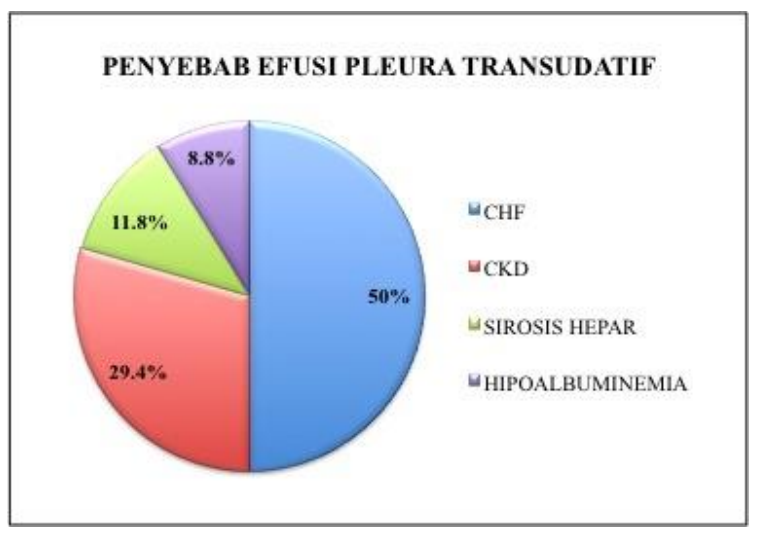

Gambar 5.3 Diagram Prevalensi Penyebab Efusi Pleura Transudatif

Dari Tabel 5.10 dan Gambar 5.3 didapatkan separuh dari 34 pasien efusi pleura transudatif disebabkan oleh gagal jantung congestif/CHF (50\%), lalu diikuti oleh CKD sebesar $29,4 \%$, sirosis hepar sebesar $11,8 \%$ dan hipoalbuminemia sebesar $8,8 \%$.
Hal ini sesuai dengan hasil penelitian Khan (2011) yang mendapatkan hasil gagal jantung sebagai penyebab efusi pleura transudatif terbanyak (62\%). Namun, pada penelitian tersebut ditemukan sirosis hepar $(16,7 \%)$ merupakan penyebab terbanyak kedua setelah gagal jantung, yang kemudian disusul oleh CKD sebesar $14,3 \%$. Jadi, CHF merupakan penyebab efusi pleura transudatif pada sebagian besar pasien.

\section{SIMPULAN}

1. Penyebab efusi pleura pada pasien rawat inap di RSUP Sanglah Denpasar, Bali selama tahun 2013 adalah malignansi, pneumonia, TB paru, demam berdarah (dengue haemorrhagic fever/DHF), komplikasi post-thoracotomy, systemic lupus erythematous/SLE, gagal jantung kongestif (congestive heart failure/CHF), gagal ginjal kronis (chronic kidney disease/CKD), sirosis hepar, dan hipoalbuminemia.

2. Penyebab efusi pleura transudatif pada pasien rawat inap di RSUP Sanglah Denpasar, Bali selama tahun 2013 adalah CHF, CKD, sirosis hepar, dan hipoalbuminemia.

3. Penyebab efusi pleura eksudatif pada pasien rawat inap di RSUP Sanglah Denpasar, Bali selama tahun 2013 adalah malignansi, pneumonia, TB paru, DHF, komplikasi post-thoracotomy, dan SLE.

\section{SARAN}

1. Bagi peneliti yang akan datang agar dapat mengembangkan penelitian ini untuk mengetahui karakteristik dan penyebab efusi pleura dengan sampel yang lebih besar.

2. Diharapkan kepada RSUP Sanglah Denpasar agar terus meningkatkan kualitas pelayanan dan prasarananya guna mengurangi komplikasi tindakan dan mengatasi komplikasi penyakit dengan lebih baik lagi.

3. Diharapkan kepada dokter dan perawat yang bertugas di RSUP Sanglah Denpasar untuk lebih melengkapi rekam medis dengan jenis cairan efusi pleura beserta pemeriksaan penunjang yang lengkap. 6.2.4 Diharapkan kepada petugas rekam medis RSUP Sanglah Denpasar untuk lebih sistematis dalam penyimpanan rekam medis dan ketepatan isi dari rekam medis pasien agar lebih mudah ditemukan, 
dipelajari, dan menunjang untuk penelitian selanjutnya.

\section{DAFTAR PUSTAKA}

1. Hooper, C. Lee, Y.C.G. Maskell, N. Investigation of a unilateral pleural effusion in adults: British Thoracic Society pleural disease guideline 2010. Thorax. 2010;65(2):ii4-ii17.

2. Brashers, V. L. Alterations of Pulmonary Function. Dalam McCance, K. L. \& Huether, S. E. Pathophysiology : The Biologic Basis for Disease in Adults and Children. $5^{\text {th }}$ Edition. Elsevier Mosby; 2006:1205-1245.

3. Rubbins, J. Pleural Effusion. 2013. Melalui http://emedicine.medscape.com/ article/299959 [02/01/14].

4. Light, R. W. Pleural Effusion. The Merk Manual for Health Care Professionals. 2012. Melalui http://www.merckmanuals.com/professional/pul monary disorders/

mediastinal_and_pleural_disorders/pleural_effus ion.html\#v923053 [02/04/14].

5. Fauci, A. S. Diseases of the Pleura and Mediastinum : Pleural Effusion. Dalam Fauci, A. S. et al. Harrison's Manual of Medicine. $17^{\text {th }}$ Edition. The McGraw-Hill Companies; 2008:777-780.

6. Desalew, M. Amanuel, A. Addis, A. Zewdu, H. Jemal, A. Pleural effusion: Presentation, causes and treatment outcome in a resource limited area,
Ethiopia. Health. 2012; 4(1):15-19.

7. Khan, F.Y. Alsamawi, M. Yasin, M. Ibrahim, A.S. Hamza, M. Lingawi, M. Abbas, M.T. Musa, R.M. Etiology of pleural effusion among adults in the State of Qatar: a 1-year hospital-based study. Eastern Mediterranean Health Journal. 2011;17(7):611-618.

8. Tobing, E. M. S. Karakteristik Penderita Efusi Pleura di RSUP H. Adam Malik Medan Tahun 2011. E-Jurnal Fakultas Kedokteran USU. 2013;1(1). Ejurnal on-line. Melalui http://jurnal.usu.ac.id/index.php/ejurnalfk/articl e/view/1354 [02/04/14].

9. McGrath, E. E. \& Anderson, P. B. Diagnosis Of Pleural Effusion: A Systematic Approach. American Journal of Critical Care. 2011;20(2):119-127.

10. Mosby's Medical Dictionary. $8^{\text {th }}$ Edition. Elsevier; 2009.

11. Peralta, R. Hypoalbuminemia. 2012. Melalui http://emedicine.medscape.com/ article/166724overview\#a0101 [02/20/2014]

12. The Kidney Foundation of Canada. Melalui http://www.kidney.ca/page.aspx? pid=339 [02/20/2014].

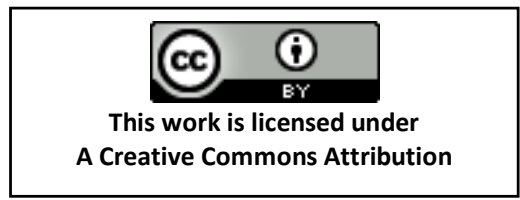


E- ISSN: 2503-3638, Print ISSN: 2089-9084

ISM VOL. 7 NO.1, SEPTEMBER-DESEMBER, HAL 57-66
โत

INTISARI SAINS MEDIS 